\title{
PELATIHAN PEMBUATAN BANTEN BYAKALA SEBAGAI WAHANA PELESTARIAN BUDAYA HINDU YANG BERLANDASKAN SATYAM, SIWAM, SUNDARAM PADA PENGABDIAN MASYARAKAT DI PURA JAGATNATHA MAYURA
}

\author{
1)I Made Ardika Yasa, ${ }^{2}$ Ni Putu Titin Suartini, ${ }^{1}$ Ni Made Laksmi Arikadanti \\ 1)Program Studi PG-PAUD, Jurusan Dharma Acarya, STAHN Gde Pudja Mataram, Mataram, Indonesia \\ 2)Program Studi Tehnik Sipil, Jurusan Teknik Sipil, Universitas Mahasaraswati Denpasar PSDKU, Mataram, Indonesia \\ Corresponding author :I Made Ardika Yasa \\ E-mail :kpjm.ardika@gmail.com
}

Diterima 07 Oktober 2021, Direvisi 21 Oktober 2021, Disetujui 21 Oktober 2021

\begin{abstract}
ABSTRAK
Agama Hindu memiliki budaya yang beraneka ragam, salah satunya ialah budaya metetuasan dimana budaya ini adalah salah satu wujud penuangan ekspresi bhakti oleh si pemuja kepada yang dipuja dalam bentuk suatu simbol yang digunakan sebagai media persembahan. Salah satu hasil dari budaya metetuasan ialah dalam bentuk banten pabersihan yang dimana banten ini merupakan banten utama didalam melaksanakan upacara keagamaan khususnya bagi umat Hindu di Bali dan Lombok. Adanya beragam persepsi tentang bentuk dan komponen unsur penyusun suatu banten pabersihan membuat Pinandita Sanggraha Nusantara Koordinator Wilayah Nusa Tenggara Barat berinisiatif melaksanakan kegiatan pengabdian ini agar dapat menyatukan persepsi dikalangan masyarakat tentang inti dari Banten Pabersihan tersebut. Salah satu banten pabersihan yang disosialisasikan dan dipraktekan pada kegiatan pengabdian yang dikemas dalam bentuk pelatihan ini ialah banten Byakala. Adapun tujuan dilaksanakannya kegiatan pelatihan "Pembuatan Banten Byakala" ini ialah sebagai wahana pelestarian budaya Hindu yang berlandaskan satyam, siwam, sundaram agar masyarakat tahu arti makna simbolis serta fungsi dari banten byakala tersebut sehingga dalam penggunaannya dapat disesuaikan dengan mempertimbangkan iksa, sakti, desa, kala dan tattwa. Dengan situasi tersebut masyarakat Hindu tidak terbebani dalam melaksanakan praktik keagamaan. Karena yang menjadi sasaran peserta dalam kegiatan pelatihan ini orang dewasa maka pendekatan yang digunakan ialah metode pendidikan orang dewasa sehingga teknis penyampaian materi pada kegiatan pengabdian kepada masyarakat ini dalam bentuk dialog interaktif dan tanya jawab yang membahas tentang segala permasalahan yang dialami peserta pelatihan terkait sarana Upakara dan kegiatan praktik tentang tetuasan ragam, variasi, sarana upakara atau banten byakala yang merupakan sarana panglukatan dalam upakara pabersihan. Dengan adanya kegiatan pengabdian ini maka dapat memberikan alternatif solusi dalam tatanan kehidupan bermasyarakat, khususnya dalam pelaksanaan kegiatan upacara Panca Yadnya kaitannya dengan banten byakala.
\end{abstract}

Kata kunci: pelatihan; banten byakala; budaya hindu.

\begin{abstract}
Hinduism has a diverse culture, one of which is the metetuas culture where this culture is a form of pouring devotional expressions by the devotee to the worshiped in the form of a symbol that is used as a medium of offering. One of the results of the metetuasan culture is in the form of the paclean offering where this banten is the main offering in carrying out religious ceremonies, especially for Hindus in Bali and Lombok. The existence of various perceptions about the form and components of the constituent elements of a PaCleanan banten made Pinandita Sanggraha Nusantara the West Nusa Tenggara Regional Coordinator to take the initiative to carry out this service activity in order to unite the perception among the public about the essence of the PaCleanan Banten. One of the offerings that are socialized and practiced in service activities that are packaged in the form of this training is the Byakala banten. The purpose of the training activity "Making Banten Byakala" is as a vehicle for the preservation of Hindu culture based on satyam, siwam, sundaram so that people know the symbolic meanings and functions of the byakala banten so that its use can be adjusted by considering iksa, magic, village, kala. and tattwa. With this situation the Hindu community is not burdened in carrying out religious practices. Because the target participants in this training activity are adults, the approach used is the adult education method so that the technical delivery of material in this community service activity is in the form of interactive dialogue and questions and answers that discuss all the problems experienced by training participants related to Upakara facilities and practical activities regarding the variety, variation,
\end{abstract}


ceremony facilities or offerings byakala which are the means of panglukatan in the paCleaning ceremony. With this service activity, it can provide alternative solutions in the order of social life, especially in the implementation of the Panca Yadnya ceremony in relation to the Byakala offering.

Keywords: training; banten byakala; hindu culture

\section{PENDAHULUAN}

Konsep dasar dan jiwa atau spirit dalam pelaksanaan ajaran agama Hindu adalah Tattwa, Susila dan Upacara. Konteks tattwa mengacu kepada maknanya sebagai acuan filosofis dan acuan kebenaran dalam ritus pelaksanaan agama Hindu yang didasarkan atas kitab suci. Sedangkan susila mengacu kepada pemaknaannya sebagai pedoman berperilaku yang didasarkan atas nilai-nilai ajaran agama Hindu (Gunada, 2020). Ketiga adalah upacara atau dalam konteks ritual keagamaan dapat dimaknai sebagai usaha untuk berserah diri kepada sang pencipta yaitu Tuhan Yang Maha ESA Dalam pelaksanaannya ketiga hal tadi tidak bisa berdiri sendiri melainkan saling melengkapi dan saling berhubungan.

Pelaksanaan keagamaan Hindu dalam realitanya secara empiris selama ini lebih menekankan kepada pelaksanaan upacara atau ritual, sehingga terkesan agama Hindu adalah agama ritual. Namun terlepas dari pandangan itu walaupun pelaksanaan ritual lebih mendominasi ritus keagamaan Hindu, nyatanya setiap prosesi upacara didasarkan atas tattwa berpedoman kepada kitab suci baik weda sruti ataupun weda smrti. Upacara sebagai cara atau strategi mendekatkan diri kepada Tuhan selalu berhubungan dengan upakara, istilah upakara mengacu kepada sebagai media yang digunakan untuk mendekatkan diri kepada Tuhan (Gunada, 2021). Maka ada suatu korelasi antara upacara dan upakara, upacara adalah strategi sedangkan upakara adalah media sehingga kedua hal ini tidak dapat dipisahkan dalam pelaksanaan keagamaan Hindu. Ada begitu banyak jenis upakara dalam ritual agama Hindu salah satunya adalah banten byakala.

Byakala sering pula disebut Byakaon. Kata Byakala berasal dari suku kata bya dan kala. Bya artinya bea, beaya atau upah dan kala adalah nama sebutan untuk para buthakala buthakali, yaitu unsur kekuatan negatif atau hal yang tidak baik karena sifatnya sering mengganggu, menimbulkan bencana, kekacauan pikiran manusia sehingga menjadi kotor dan terganggu. Sedangkan Kata Byakaon terdiri dari kata bya dan kaon. Kaon (bahasa bali) artinya buruk. Byakala atau Byakaon merupakan sarana persembahan, yang berfungsi menetralisir kekuatan negatif menjadi positif kaitannya dengan waktu, kala (energi) sehingga tercipta keharmonisan lingkungan (Arwati, 2003)

Adapun Penggunaannya Banten Byakala atau Byakaon itu sering dipergunakan dalam upacara agama Hindu sebagai proses awal upacara yaitu sebelum upacara inti dilaksanakan. Dalam upacara Manusia Yadnya Byakala itu mulai dipergunakan sejak anak itu mulai tanggal gigi atau Maketus sampai tua, terutama dalam pelaksanaan upacara Oton yaitu peringatan terhadap hari kelahirannya, bertepatan dengan hari dalam Saptawara, Pancawara dan Wuku, yaitu setiap enam bulan sekali atau 210 hari sekali (Sudana, 2001).

Dalam upacara Dewa Yadnya seperti Piodalan, Galungan, Pagerwesi dan lain sejenisnya, disesuaikan dengan desa, kala, tattwa. Byakala itu dihaturkan sebelum upacara inti yang berfungsi sebagai sarana pabersihan lingkungan, sesuai konsep ajaran Tri Hita Karana. Selain itu Byakala juga dipersembahkan sebagai pelengkap dalam tatandingan banten Caru. Cara mempersembahkannya jika ngayab ke pelinggih maka dihaturkan ke bawah, dan pada manusia di ayab menuju puser atau difokuskan pada areal kaki. Bahan dasar dari banten byakala/byakaon adalah dapat dengan daun andong merah, slepan, dan sampian nagasarinya bisa dengan menggunakan busung. Fungsinya sebagai simbul dari dewa brahma (merah) (Surayin, 2002).

Secara pragmatis pelatihan pembuatan sarana banten byakala sebagai upakara dalam ritual keagamaan Hindu merupakan penguatan pemahaman mengenai makna banten byakala dan keterampilan dalam membuat sarana banten tersebut. Karena konsep ritual keagamaan Hindu tidak bisa dilepaskan dari sesanti satyam, siwam dan sundaram. Makna satyam adalah kebenaran, siwam adalah kesucian dan sundarama adalah kesimbangan (Gunada, 2020). ketiga hal tersebut maka akan membentuk suatu keseimbangan dalam pemahaman dan pelaksanaan ritus-ritus keagamaan Hindu. Disamping itupula tujuan penulisan hasil pengabdian kepada masyarakat ini merupakan bentuk sumbangsih pengetahuan untuk aplikasi teori dalam praktek kehidupan sehari-hari sehingga konsep ajaran agama Hindu salah satunya dalam sarana banten byakal dapat diketahui oleh umat dan 
dapat dibuat secara mandiri, disamping pula diharapkan kedepan kegiatan ini dapat kembali dilakukan untuk menguatkan sradha dan bhakti umat sehingga tetap yakin dan melestarikan keyakinan dirinya terkait ajaran-ajaran agama Hindu.

\section{METODE}

Dosen merupakan tenaga pendidik pada suatu perguruan tinggi yang memiliki tugas utama ialah menjalankan tri dharma perguruan tinggi yaitu melaksanakan pendidikan, penelitian dan pengabdian kepada masyarakat, pada aspek Pengabdian kepada masyarakat dosen memiliki kewajiban untuk melakukan suatu aktivitas kegiatan resmi yang memiliki nilai manfaat kepada masyarakat. Dosen bisa melaksanakan pengabdian kepada masyarakat melalui organisasi kemasyarakatan ataupun secara mandiri. Pengabdian ini dilaksanakan dalam bentuk pelatihan pembuatan Banten Byakala dengan tujuan mengenalkan makna filosofi yang terkandung dalam simbol yang terdapat pada banten byakala dan melatih keterampilan tentang cara membuat Banten Byakala kepada generasi muda Hindu sebagai penerus dalam menjaga Budaya Hindu yang berdasarkan pada prinsip umat Hindu yaitu satyam, siwam, sundaram sehingga dapat memperkuat iman dan takwa kepada Tuhan yang Maha ESA.

Kegiatan pengabdian kepada masyarakat dalam bentuk pelatihan ini memilih lokasi kegiatan di Pura Jagadnatha Mayura berdasarkan hasil rapat dan musyawarah pertimbangan dari pengurus PSN Korwil Nusa Tenggara Barat dengan pertimbangan bahwa pura Jagatnatha mayura sangat signifikan untuk mendukung kelancaran, kenyamanan dan keamanan melaksanakan kegiatan tersebut sebab sarana dan prasarananya sangat memadai, areal tempat pelaksanaan pelatihan luas dan areal tempat parkir yang sangat luas serta dekat dengan pusat kota selain itu pengelola pura dan taman mayura juga sangat mendukung adanya kegiatan positif yang tujuanya untuk kepentingan Umat Hindu. Setiap kegiatan pastinya memiliki jadwal sebagai dasar melaksanakan kegiatan demikian halnya dengan pelatihan Pembuatan Banten Byakala ini tersusun jadwal seperti yang tercantum pada Table.1. berikut ini:

Tabel.1. Jadwal Pelatihan Pembuatan Banten Byakala

\begin{tabular}{lc}
\hline \multicolumn{1}{c}{ Kegiatan } & Tanggal kegiatan \\
\hline 1. Pembuatan TOR & 11-13 Desember \\
kegiatan & 2020 \\
2. Menyusun & 14 Desember 2020 \\
Kepanitiaan & \\
\hline
\end{tabular}

\begin{tabular}{|c|c|}
\hline $\begin{array}{l}\text { 3. Persiapan } \\
\text { pelaksanaan }\end{array}$ & $\begin{array}{c}\text { 15-20 Desember } \\
2020\end{array}$ \\
\hline 4. Penyampaian & \\
\hline $\begin{array}{l}\text { Materi Filsafat } \\
\text { Yadnya }\end{array}$ & 9 Januari 2021 \\
\hline 5. Penyampaian & \\
\hline $\begin{array}{l}\text { Materi Upacara } \\
\text { Agama Hindu dan } \\
\text { materi Upakara } \\
\text { Yadnya }\end{array}$ & 10 Januari 2021 \\
\hline 6. Penyampaian & \\
\hline $\begin{array}{l}\text { materi dan } \\
\text { Praktek Saran } \\
\text { Pabersihan } \\
\text { Bayekaon/ } \\
\text { Bayakala }\end{array}$ & 17 Januari 2021 \\
\hline $\begin{array}{l}\text { 7. Penyampaian } \\
\text { Materi Prayascita } \\
\text { dan Durmanggala, } \\
\text { Praktek } \\
\text { Pembuatan } \\
\text { Prayascita dan } \\
\text { Durmanggala }\end{array}$ & 24 Januari 2021 \\
\hline $\begin{array}{l}\text { 8. Penyampaian } \\
\text { Materi dan praktek } \\
\text { etika metanding }\end{array}$ & 31 Januari 2021 \\
\hline $\begin{array}{l}\text { 9. Monitoring, } \\
\text { Evaluasi dan } \\
\text { pelaporan } \\
\text { kegiatan }\end{array}$ & 1-5 Februari 2021 \\
\hline
\end{tabular}

Didalam melaksanakan kegiatan pelatihan pembuatan Banten Byakala ini terdapat beberapa tahapan yang dilalui yaitu;

\section{Tahap Pra Kegiatan}

Sebelum kegiatan pengabdian dilaksanakan terlebih dahulu Panitia pelaksana mengadakan diskusi, sharing dan mengumpulkan informasi lalu konfirmasi, konsultasi, serta koordinasi terlebih dahulu kepada Ketua pengurus Pinandita Sanggraha Nusantara (PSN) Koordinator Wilayah Nusa Tenggara Barat agar memperoleh saran dan masukan terkait sasaran pelaksanaan kegiatan pengabdian, setelah memperoleh masukan maka ditetapkan lokasi diadakannya pelatihan ini ialah di areal Pura Jagat Natha Mayura yang diikuti oleh 50 orang peserta yang terdiri dari berbagai kalangan yaitu istri pemangku, dosen Institut Agama Hindu Negeri Gde Pudja Mataram, mahasiswa Institut Agama Hindu Negeri Gde Pudja Mataram, dan masyarakat beragama Hindu lainnya.

Tahap ini juga membahas tentang rencana dan program, persiapan perencanaan Pelatihan yang mencakup penyusunan kepanitaan melalui rapat pengurus PSN Koordinator wilayah Provinsi Nusa Tenggara Barat sekaligus matur piuning dengan 
rangkaian persembahyangan bersama seluruh pengurus koordinator wilayah Nusa Tenggara Barat, usulan pengajuan judul, melakukan pengumpulan, pengolahan, klarifikasi dan penyajian data lokasi pengabdian masyarakat, penyusunan Surat Keputusan, dan penyusunan Rencana Anggaran Biaya.

\section{Tahap Kegiatan}

Ini merupakan Tahap Kedua yaitu tahap dimana rencana dan kegiatan dilaksanakan sehingga pada tahapan ini pelaksana pengabdian menentukan susunan acara program kegiatan pengabdian masyarakat, rencana persiapan sarana dan prasarana pendukung kegiatan, merumuskan tindak lanjut pelaksanaan kegiatan dan pelaksana rencana kegiatan;

Pada awal kegiatan peserta pelatihan diberikan semacam pertanyaan dan uji coba tes awal secara lisan tentang banten byakala untuk mengetahui sejauh mana pengetahuan keterampilan, dan kemampuan dasar peserta tentang banten byakala sebelum mengikuti pelaksana kegiatan Pelatihan Sarana Banten Byakala menerima materi dalam bentuk Praktik, Ceramah, dan diskusi serta tanya jawab dari para peserta. Dan dipenghujung kegiatan peserta pelatihan pembuatan banten byakala diberikan post tes untuk mengetahui hasil pencapaian kegiatan pelatihan yang disampaikan oleh pelaksana kegiatan Pengabdian masyarakat yang diadakan oleh PSN Koordinator wilayah Nusa Tenggara Barat. Selama Kegiatan Pelatihan materi disampaikan menggunakan alat bantu alat praga yang disediakan tim panitia dan didukung secara sukarela oleh peserta pelatihan.

Pelatihan Pembuatan Banten Byakala ini sasaran utamanya adalah orang dewasa, maka untuk memacu motivasi, semangat, antusias Peserta mengikuti kegiatan pelatihan pembuatan Banten Byakala maka didalam pelaksanaan kegiatan pelatihan pada lokasi pengabdian, pelaksana kegiatan dominan menggunakan metode diskusi kelompok dan metode tanya jawab dalam kegiatan pelatihan. Metode diskusi Kelompok adalah salah satu strategi belajar-mengajar yang sesuai untuk proses belajar mengajar yang dilaksanakan oleh seorang pendidik bertujuan untuk mendorong munculnya faktor-faktor positif dalam diri seorang peserta didik dengan menggunakan materi atau gaya penyampaian materi yang memancing agar peserta didik terlibat untuk menyampaikan dan menemukan alternatif pemecahan suatu topik bahasan yang bersifat problematis. (Latifah, 2013)
Selain itu agar peserta didik merasa senang dan nyaman dalam mengikuti pelatihan maka didalam kegiatan pelatihan Pelaksana Kegiatan juga menggunakan metode tanya jawab dimana pendidik memberikan pertanyaan kepada peserta didik dan pendidik juga mengambil nilai dari pertanyaan yang bisa dijawab oleh peserta didik tersebut, dengan adanya metode tanya jawab tersebut maka wawasan dari pendidik dan peserta didik akan menjadi lebih luas yang tidak hanya sekedar terpaku pada teori pada materi yang didampaikan saat pelatihan saja sebab didalam tanya jawab tersebut terdapat cara penyajian pelajaran dalam bentuk pertanyaan yang didampaikan oleh peserta didik (Ahmad \& Tambak, 2017)

\section{Tahap Monitoring Evaluasi}

Tahap ke tiga ini pelaksanaan proses monitoring dan evaluasi menggunakan media aplikasi zoom meeting sebab mengingat situasi dan kondisi masa pandemik ini tidak memungkinkan dan tidak diperkenankan untuk melakukan aktivitas kegiatan yang menimbulkan kerumunan masa. Adapun tekhnis pelaksanaan kegiatan monitoring dan evaluasi ialah sebagai berikut;

1.Peserta dikumpulkan didalam satu komunitas menggunakan aplikasi Group Whatsapp untuk mempermudah penyampaian informasi dan komunikasi terkait kegiatan pelatihan.

2.Setelah itu panitia membagikan informasi terkait kegiatan serta tautan kanal zoom meeting pada aplikasi Group Whatsapp.

3.Tim Panitia mengobservasi serta melakukan komunikasi kepada peserta pelatihan secara lisan untuk menggali data dan informasi terkait kegiatan pelatihan sehingga diperoleh data yang memuat tentang ketercapaian kegiatan pelatihan baik dari segi perubahan pengetahuan, kemampuan, dan keterampilan dengan sistem tanya jawab.

4.Setelah mendapatkan data dan informasi terkait pelaksanaan kegiatan pelatihan maka seluruh data dan informasi tersebut di reduksi, dan dianalisis.

5.Dan pada tahap terakhir peserta pelatihan diminta untuk mengumpulkan video praktik pembuatan sarana banten Byakala perkelompok secara mandiri tanpa didampingi oleh mentor.

\section{Tahap Pelaporan}

Ditahap keempat ini merupakan tahap akhir dari suatu kegiatan, maka hasil dari reduksi dananalisis data pada kegiatan monitoring dan evaluasi tersebut maka ditindak lanjuti dalam bentuk laporan kegiatan pelatihan pembuatan banten byakala secara tertulis dan 
sistematis setelah laporan tersebut selesai disusun oleh pelaksana kegiatan maka laporan tersebut diserahkan kepada Ketua PSN Koordinator Wilayah Nusa Tenggara Barat untuk di periksa dan dikoreksi jika ada yang kurang tepat dan perlu diperbaiki maka paniia pelaksana harus merevisi laporan tersebut hingga memperoleh tanda pengesahan sebagai tanda persetujuan diterimanya laporan pelaksanaan kegiatan tersebut. Dengan diterimanya laporan pelaksanaan kegiatan maka berakhirlah kegiatan pelatihan yang telah dilaksanakan, setelah berakhirnya kegiatan Pelatihan maka dilakukan kegiatan pembubaran panitia. Dan laporan kegiatan yang telah disahkan dapat digunakan sebagai bahan yang akan dilaporkan kepada PSN Pusat serta keinstansi tempat tim panitia pelatihan bekerja sebagai bukti pertanggungjawaban telah melaksanakan kegiatan sesuai dengan surat tugas yang telah diberikan yaitu mengikuti Pelatihan Pembuatan Banten Byakala.

\section{HASIL DAN PEMBAHASAN}

Merujuk dari hasil analisis kegiatan Pelatihan pembuatan banten byakala yang diselenggarakan PSN Koordinator Wilayah Nusa Tenggara Barat yang telah dilaksanakan bertempat di Pura Jagatnatha Mayura maka diperoleh hasil yaitu;

Seperti halnya pelatihan pada umumnya, kegiatan pelatihan ini juga pastinya berpedoman pada jadwal rencana kegiatan sebelum pelatihan tersebut dilaksanakan, sehingga kegiatan pelatihan berjalan lancar dan sukses. Pelatihan pembuatan banten Byakala ini dilaksanakan sesuai rencana yang telah di susun dan dirancang pada jadwal kegiatan yaitu pada tanggal 09 Januari 2021 yang tercantum ditabel 1.

Pelatihan Pembuatan banten byakala ini mendapat tanggapan baik dari kalangan masyarakat hal itu terlihat dari banyaknya peserta yang mendaftar untuk mengikuti kegiatan pelatihan pembuatan banten byakala ini namun panitia tidak dapat mengakomodir lonjakkan antusias peserta yang mendaftar pada kegiatan pelatihan Pembuatan Banten Byakala ini disebabkan oleh adanya pembatasan aktivitas yang dapat menimbulkan kerumunan masa karena situasi pandemi dan sesuai protokol kesehatan jumlah peserta disesuaikan dengan kondisi lokasi tempat pelaksanaan kegiatan dimana lokasi tempat pelatihan idealnya hanya memuat maksimal 50 orang peserta. Walau demikian tidak mengurangi semangat peserta untuk mengikuti pelatihan bahkan peserta menjadi semakin antusias mengikuti kegiatan karena merasa beruntung menjadi peserta yang terpilih mengikuti kegiatan pelatihan karena lolos seleksi hal itu terlihat dari peserta yang sungguh-sungguh mengikuti kegiatan pelatihan baik pada sesi teori ataupun sesi praktik sehingga timbul berbagai berbagai pertanyaan dari peserta pelatihan yang sifatnya problematis ataupun pertanyaan yang menjurus pada materi yang diberikan oleh pemateri, adapun beberapa pertanyaan tersebut terangkum sebagai berikut; 1 . Pertanyaan dari Ni Nyoman Lala Sri Utami Mengapa orang-orang Hindu (Bali ) banyak sekali melaksanakan upacara upacara agama?, dan jawabanya: Karena agama Hindu menganut ajaran siwa sidhanta. Agama Hindu yakin dengan ajaran Panca Sradha (5 keyakinan), Pertanyaan ke 2 dari I Gusti Ayu Bambang, Apakah perbedaan dari banten - banten byakala 1 , byakala 2 , byakala 3 dan digunakan pada saat kapan banten byakala tersebut ? dan jawabanya ialah Semua banten itu hanyalah modifikasi yang menghasilkan variasi jenis banten byakala, untuk menambah wawasan tentang pengetahuan ragam byakala, walaupun berbeda namun esensi penggunaan banten byakala sama. yaitu untuk penyucian alam bhur (bawah). Banten byakala dfungsinya untuk sarana pembersihan areal lingkungan seperti di areal pelinggih atau pura (diayab kebawah), pada upacara manusia yadnya (pawiwahan, otonan, hari raya penampahan galungan) dan pada upacara mecaru. Anak yang belum tanggal giginya tidak mebyakala karena masih tergolong sifat kedewataan.

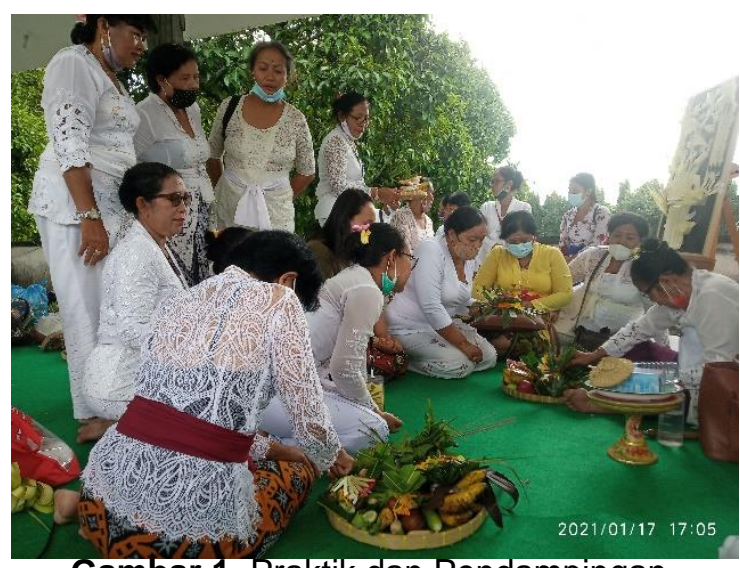

Gambar 1. Praktik dan Pendampingan

Pembuatan Banten Byakala ( Sumber: I Made Ardika Yasa)

\section{Jenis-Jenis Banten Byakala berdasarkan unsur pendukungnya.}

Banten byakala merupakan salah satu banten pabersihan yang memiliki jenis yang beragam berdasarkan unsur pendukungnya, 
adapun jenis-jenis banten byakala tersebut ialah sebagaiberikut;

\section{a. Banten Byakaon}

Banten byakaon adalah salah satu dari banten byakala yang dimana unsur penyusun banten tersebut terdiri dari sebuah sidi, aledan sayut, berisi kulit peras pandan berduri, Rakaraka sampian nagasari, Pesucian,Sebuah lis amuan-amuan,Sebuah nasi metajuh, sebuah ceper berisi base tulak, takir berisi beras kuning, tempurung berisi nasi berwarna hitam, telor ayam mentah,Kojong rangkat Nasi kepel agung metancep bawang tabia, sebuah nasi metimpuh, sebuah sabet dari serabut kelapa,3 katih lidi, sebuah penyeneng dan Payuk pere.

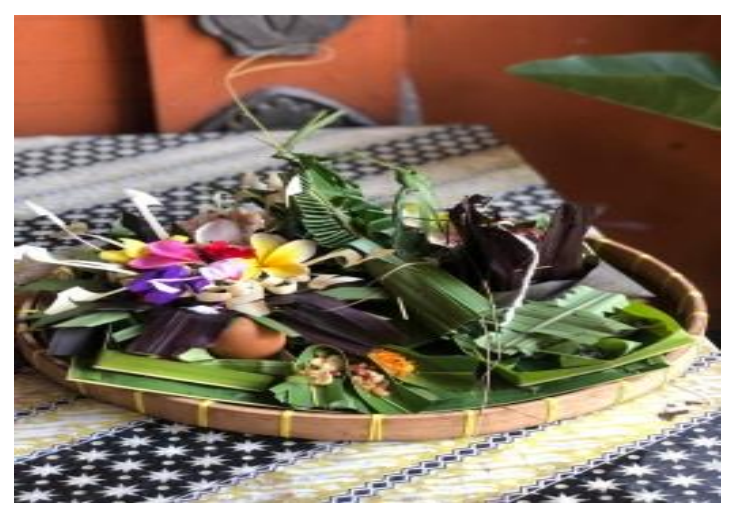

Gambar 2. Banten Byakaon ( Sumber: Jero Mangku Ni Komang Wiasti)

\section{b. Banten Byakala 1}

Banten Byakala 1 merupakan banten byakala yang unsur pembentuknya terdiri dari menggunakan alas tempeh sidi. Di atas sidi diletakkan satu buah taledan sebagai alas, raka-raka dan kelengkapanya. Di tengahtengah taledan diisi sejumput beras, benang dan sebuah tampelan. Di atasnya di taruh sebuah kulit peras dari pandan (tiga pucuk pandan). $\mathrm{Di}$ atas kulit peras nasi yang dibungkus: satu slekos sumping, satu slekos segi tiga. Kojong rangkadan. Sampiyan nagasari, sesedep berisi beras putih dan benang putih. Coblong berisi air dan sebuah padma. Satu tanding pasucian, Satu tukir isuhisuh berisi sapu lidi-tulud sambuk dan danyuh, satu takir benang merah, canang.

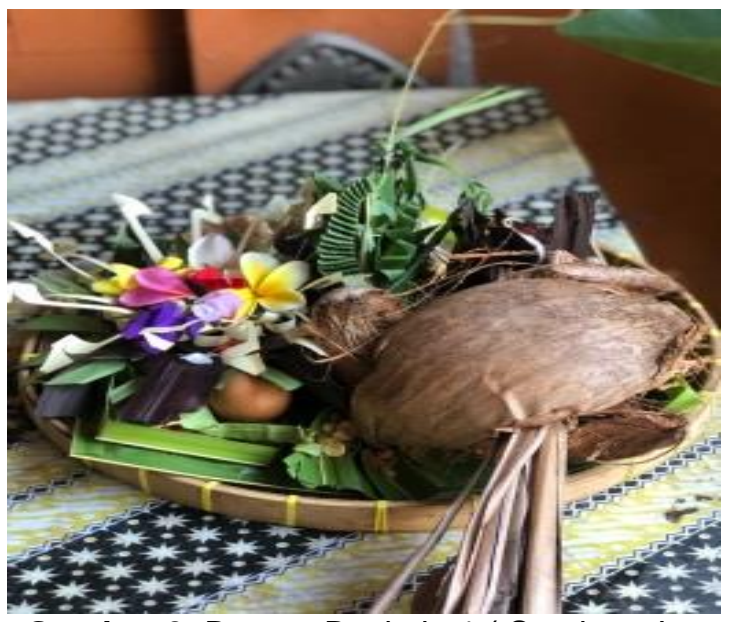

Gambar 3. Banten Byakala 1 ( Sumber: Jero Mangku Ni Komang Wiasti)

\section{c. Banten Byakala 2}

Banten ini terbentuk dari komposisi unsur; tempeh, kulit sesayut, kulit peras dari daun pandan, nasi bungkus daun pisang berbentuk segi empat, selanjutnya nasi dibungkus daun pisang sebanyak tiga bungkus berbentuk segi tiga, panek among yang di susuni bawang, jahe dan terasi, disekitarnya diisi lauk-pauk, buahbuahan, jajan dan sampyan nagasari dari daun andong dilengkapi dengan beberapa perlengkapan seperti:

- Pesucian,Isiuh-isuh: ceper berisi sebutir telur ayam mentah, sapu lidi kecil (sebelas batang), sapu sabut kelapa dijepit lidi, base tulak, ramuan yang terbuat dari: kayu tulak, kayu sisih, lalang, daun dadap, padang lepas yang semuanya beralaskan sebuah tangkih. Amel-amel: sebuah limas berisi tiga lember daun dadap, padang lepas, wel mingmang, semuanya diikat dengan benang tridatu (merah, putih, hitam)

- Sasak mentah: tiga pulung nasi bertempatkan tengkulak (tempurung batok kelapa), dicampur darah mentah, trasi dan bumbu rajang.

- Peras, tulung, ajengan, Buwu (lis amuamuan, Padma

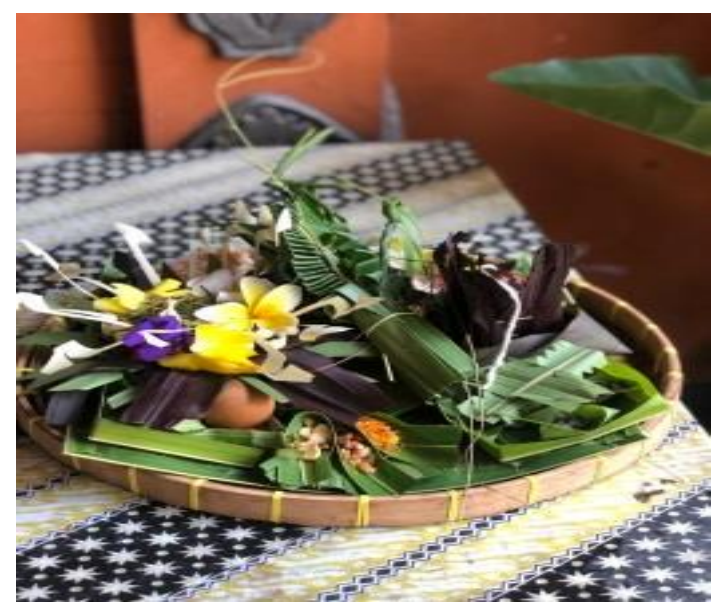


Gambar 4. Banten Byakala 2 ( Sumber: Jero Mangku Ni Komang Wiasti)

\section{d. Banten Byakala 3}

Banten byakala 3 dibuat dari beberapa unsur yaitu Sebuah sidi, taledan tajuh, berisi kulit peras pandan berduri, raka-raka,Sebuah sampian nagasari, pesucian, sebuah lis amuanamuan, sebuah nasi metajuh,sebuah ceper berisi base tulak, takir berisi beras kuning, tempurung berisi nasi berwarna hitam, telor ayam mentah,Kojong rangkat Nasi kepel agung metancep bawang tabia Sebuah nasi metimpuh,Sebuah sabet dari serabut kelapa,3 katih lidi,Sebuah penyeneng,Payuk pere, sampian nagasari, canang.

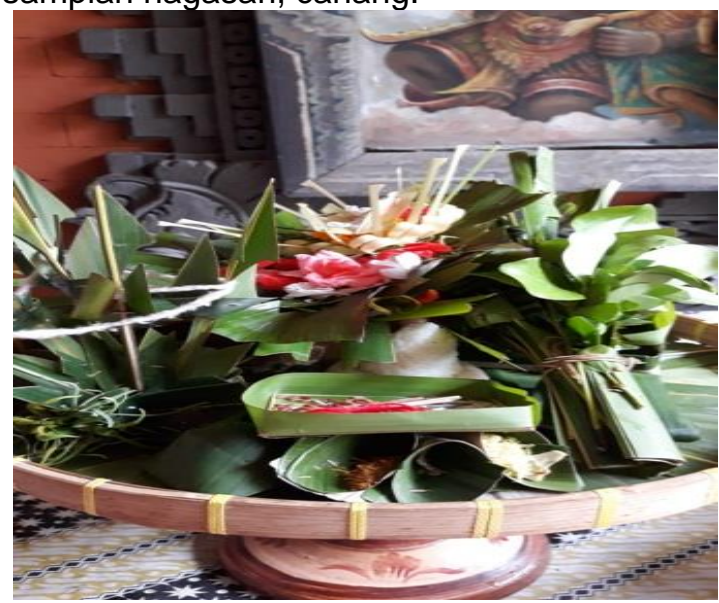

Gambar 5. Banten Byakala 3 ( Sumber: Jero Mangku Ni Komang Wiasti)

\section{e. Banten Byakala Agung}

Banten Byakala Agung ini terdiri dari sidi sebagai alasnya, kulit sesayut, diatas kulit sesayut ditumpuk atau boleh juga ditempelkan aled peras yang dibuat dari daun pandan berduri atau disebut pandan wong. kedua jenis jejahitan tersebut yaitu kulit sesayut dan aled peras, diatas aled peras, disusuni dengan nasi matimpuh, nasi matajuh, kemudian diatasnya diletakkan sebuah penek hamong, yang disisipi dengan bawang merah, jahe dan terasi mentah. nasi matimpuh adalah nasi bercampur garam dibungkus dengan daun berbentuk persegi empat. nasi matajuh, adalah nasi bercampur garam dibungkus dengan daun berbentuk segi tiga,sampian nagasari, isuh-isuh, alasnya mempergunakan sebuah ceper, didalamnya berisi perlengkapan seperti :

Satu butir telur ayam mentah, satu ikat sapu lidi, satu tangkai sabet dibuat dari sepotong lidi/bambu kecil yang dibagi dua pada bagian ujungnya, kemudian dimasukkan serabut kelapa lalu diikat, Base Tulak, satu buah Celemik yang didalamnya berisi ramuan dari daun lalang, dadap, daun kayu tulak, daun kayu sisih ditumbuk menjadi satu, Amel-Amel, Alasnya memakai sebuah ituk-ituk, didalamnya berisi tiga lembar daun dadap, tiga cabang ujung dadap, padang lepas, seet mingmang yang dibuat dari tiga lembar ujung daun lalang pada ujungnya diikatkan, lalu semua bahan diikat jadi satu dengan benang tridhatu yaitu tiga macam benang berwarna hitam, putih dan mentah,Sasak Mentah.Alasnya memakai sebuah limas atau dapat pula memakai tempurung kelapa (kau bulu,bahasa Balinya). Diatasnya berisi tiga pulung nasi disirami dengan darah mentah, bumbu rajang dan terasi mentah,Pesucian, Sorohan Alit.Terdiri dari tiga jenis Banten, yang diikat jadi satu. Ketiga Banten itu adalah Peras, Tulung dan Sesayut.Peras, tulung, sayut ( slepan Gadang) Aledan Sampian nagasari, penyeneng, (daun andong) sambuk Lis Byakala. Semua jenis jejahitan untuk Lis Byakala dibuat dari daun janur hijau atau slepan. Adapun jenis jejahitannya, terdiri dari : Tangga Menek, Tangga Tuwun, Jan Sesapi, Lilit Linting, basang Nguda, Basang Wayah, Lawat Buah, Lawat Nyuh, Tipat Pusuh, Tipat Tulud,Sasap, Takep Jit Lis.

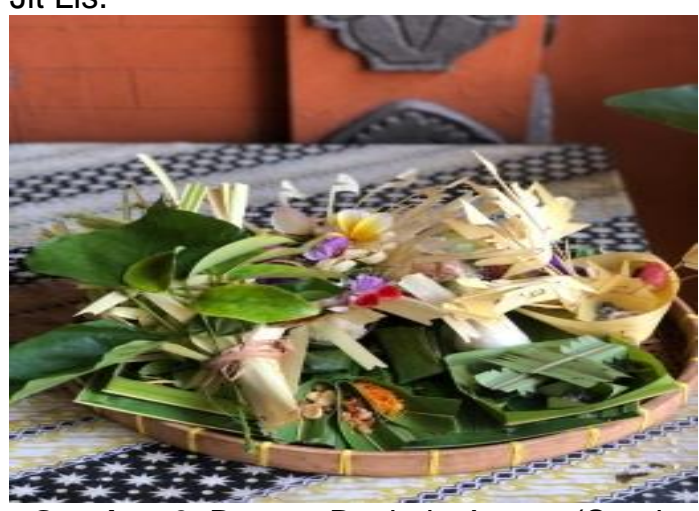

Gambar 6. Banten Byakala Agung (Sumber: Jero Mangku Ni Komang Wiasti)

\section{Penjelasan unsur dari byakala dan pertanyaan dari peserta pelatihan terkait banten byakala.}

Pada kegiatan pelatihan pembuatan banten byakala pemateri/narasumber menjelaskan jenis-jenis banten byakala, unsur pembentuk sarana banten byakala dan tanya jawab atas pertanyaan problematis peserta pelatihan terkait materi yang disampaikan pada kegiatan pelatihan pembuatan banten Upacara bayakaon, penjelasan tentang hal tersebut sebagai berikut;

\section{a. Unsur dari Banten Byakala}

Adapun unsur inti yang membentuk banten byakala pada umumnya harus terdiri dari bahan berikut;

1. Isuh-Isuh terdiri dari Ceper, telur ayam mentah/ bawang merah yang dikupas, 3 buah sapu lidi, serabut kelapa, base tulak/porosan, daun-daunan yang disisir 
terdiri dari daun kayu tulak, kayu sisih, kemuning, padang lepas, daun alangalang dan daun dadap.

2. Amel-amel terdiri dari Sebuah limas, diisi daun dadap, ujung daun dadap masingmasing 3 buah lalu diikiat dengan benang merah, putih dan hitam, kemudian dilengkapi dengan set mingmang.

3. Sasak Mentah terdiri dari 3 buah limas yang berisi 3 kepel nasi yang disirami dengan darah mentah, dilengkapi dengan bumbu rajang sorohan alit terdiri dari peras tulung sesayut (kecil)

4. Lis Pebyakala (Bebu'u) terdiri dari Tangga menek, tangga tuun, jan, sesapi, lawat buah, lawat nyuh, linting, lawangan, tipat pusuh, tipat tulud, basang wayah, basang ngude, siku, ntud, sendok ampet.(takep jit).

5. Sesedep terdiri dari Beras, benang, uang

6. Sesarik terdiri dari Daun sirih, kapur, pinang di haluskan

7. Reranggitan terdiri dari Bunga jepun yang disisir halus dan beras kuning

\section{b. Tanya jawab seputar banten byakala}

1.Sebelum memulai mejejaitan doa napi yang kita Ucapkan?

Jawab : Untuk melatih sadhana spiritual sebagai orang Hindu baiknya kita berdoa sebelum melakukan kegiatan apapun, Bisa dengan "Om Awighnam astu namo sidham" (semoga pekerjaan hamba berhasil tanpa halangan) atau "om Prano Dewi saraswati, wajebhir wajiniwati dhinam anwinyawantu" (memohon inspirasi).

2.Kenapa saat prosesin ngayabin ataupun ngetisin pakai banten prayascita kearah atas, durmangala kebawah dan byakawon ke belakang?

Jawab : karena banten tersebut untuk sarana penyucian yang tujuannya menetralisir kekuatan negative yang berasal dari 3 alam, sesuai dengan kandungan unsur dan sifat dasar persembahannya. Agar menjadi positif sehingga menciptakan keharmonisan. Proses ngayab bermakna sebagai penyucian Tri Kaya Parisudha, dan Penyucian ke 3 alam, alam bhur, bwah dan swah, sehingga menciptakan keseimbangan

3.Apakah Arti makna dan filosofis dari Banten Bayekaon?

Jawab: baya artinya bahaya, kaon artinya buruk, menghilangkan (byakaon artinya sarana banten menghilangkan hal-hal yang sifatnya kurang baik) Byakala (kaitannya dengan waktu, energi. Jika dihubungkan dengan perasaan seseorang maka banten byakala artinya banten yang dapat menetralisir hal-hal negative yang dapat mengganggu pikiran sehingga menimbulkan perasaan yang tidak baik misalnya perasaan kesel, marah dll, sehingga menciptakan sifat kedewataan.

4.Mengapa banten byakaon tidak menggunakan sambuk, sedangkan pada banten byakala menggunakan. Apa perbedaan dari kedua banten tersebut.

Jawab: Kalau yang menggunakan sambuk dipergunakan pada upacara manusia yadnya, fungsinya sebagai pesaksi (simbul dualitas keseimbangan) sedangkan jika dewa yadnya tidak menggunakan sambuk. Banten byakaon dipergunakan pada upacara dewa yadnya dan byakala pada upacara manusia yadnya. Perbedaan dari kandungan unsurnya kalau ke manusia kandungan unsurnya lebih banyak.

5.Apa saja isi dari penyeneng. Byakala/byakaon, mengapa ada yang memakai aledan sayut dan aledan tayuh. Yang mana yang benar?

Jawab: Penyeneng berasal dari kata nyeneng (artinya hidup), 3 buah lekukan membentuk keseimbangan bayu sabda idep, isinya tepung tawar, kekosok, dan kapas, diselipkan porosan dan bunga rampe. Aledan sesayut bundar artinya simbul bulan dan bisa juga bulat sebagai proses kehidupan yang bertahap ibarat roda, metajuh (simbul matahari) memiliki 4 sisi sebagai catur loka, arah mata angin, timur, selatan, barat, dan utara

6.Bagaimana tata cara melaksanakan byakala/yakaon?

Jawab: Kalau dipergunakan kedewa ayab ke atas, dicaru ayab ke sor sedangkan upacara manusia yadnya tahapannya sebagai berikut : Nyalakan sambuk dan danyuh, Usapin tangan dengan Toya anyar, gelar pesucian, basahi dengan air, kemudian isuh-isuh selengkapnya telur letakkan dibawah , pelukatan, tirtha ketisin kebawah, lalu sentuh-sentuhkan jempol kaki dengan telur sebanyak 3 kali, ayab ke samping disilang atau kebawah, atau ke pusar dengan menjepit benang merah dan sahkan dengan dengan menekan nasi sumping bagi laki-laki, telekos bagi perempuan, dan merobek sampian dan kulit peras.

8. Mengapa harus menggunakan sidi pada banten Byakala/Byakaon?

Jawab: Banten/upakara Bahasa weda (mona). Karena dengan sidi banten 
byakala tersebut dapat diterjemahkan maknanya yaitu untuk menyaring kotoran ibarat sidi, yang kotor, kasar menjadi halus.

9. Pada tetandingan banten byakala menggunakan pandan wong (pandan berduri) yang dibentuk seperti kulit peras. Bagaimana arah pasang antara kepala dan ekor atau kepala-kepala berderet. Berapakah kita menggunakan pandan wong ini?

Jawab : Pandan wong dipergunakan pada banten byakala tujuannya karena sifanya pandan wong adalah berduri, dan tajam, seperti itulah diibaratkan hidup kita dengan makna banten tersebut, hidup kita kadangkala sulit (sakit), ada rintangan, halangan, dinetralisirlah dengan banten byakala/bayekaon. Pada banten byakala menggunakan 5 helai kulit peras dari panda wong yang artinya simbul dari panca maha bhuta, masalah kepala dan ekor silahkan dikreasikan menurut seni keindahan masing-masing, mau divariasikan selang-seling, kepala, ekor itu boleh-boleh saja tidak mempengaruhi. Jika diselang seling baiknya yang kepalanya 3 di hulu, atau menghadap atas.

10.Untuk sabet napi manten isinya, apakah hanya serabut kelapa saja ataukah ditambahkan dengan daun alang-alang? Jawab : Untuk sabet dibuat dari kelapa (sambuk dibentuk seperti kipas keci), merupakan kelengkapan isuh-isuh (telur, sabet, dan daun-daunan, kemuning, dadap, sisih, tulak, padang lepas)

11. Untuk Ramuan Isuh-isuh apa saja isinya? Karena ada beberapa buku menuliskan daun lalang, daun dapdap, daun kayu tulak, dan daun kayu sisih yang ditumbuk halus. Namun dibuku lain saya mendapatkan selain daun lalang, daun dadap, daun kayu tulak dan daun kayu sisih ada ditambahkan daun ancak dan daun bingin. Sementara di buku lain ada ditambahkan daun kemoning. Mohon penjelasannya.

Jawab : diantaranya ( telur ayam, sabet, lidi 3 katih, serabut kelapa, base tulak, daun-daunan). Daun lalang (ujungnya runcing, tajam pada sisi kiri kanannya, kemuning (ning, suci) daun dadap (daun kayu sakti karena memiliki 3 helai daun), daun kayu tulak (penolak), daun kayu sisih (memilah, menyisihkan). Oleh karena Lontar bebantenan sangat banyak umat Hindu miliki, maka sesungguhnya semua refrensi tujuan dan fungsinya sama. Tidak ada yan g salah dan tidak ada yang kurang. Hanya saja perlu wiweka untuk mencerna, silahkan pilih yang paling simple, sederhana, mudah dijangkau

12. Untuk amel-amel napi saja isinya? Karena ada buku yang mencatatkan 3 ujung daun dapdap, 3 lembar daun dapdap, seet mingmang dan 3 daun padang lepas. Namun di buku lain tidak dicantumkan padang lepas.

Jawab : Amel-amel isinya ujung batang dadap 3, diikat benang tri datu, dan ambengan set ming mang. Mungkin jawaban hampir sama dengan pertanyaan di atas, oleh karena banyaknya sumber bebantenan yang umat Hindu miliki sehingga jangan sampai terkecoh, merasa, bersalah dan kurang.Kita tidak terpaku sama 1 sumber perlu sumber lain sebagai pembanding. Konsep persembahan adalah ketulusan, yang terpenting aplikasikan Tri Hita Karana, Tri Kaya Parisudha, Catur Purusa Artha dan ajaran weda sungguh baik.

13. Pengresikan atau pesucian atau kadang disebut kerik kramas nike perlengkapannya apa saja? Dan napi makna dari masing-masing alat-alat pelengkap kerik keramas tersebut.

Jawab : Pesucian/Krikramas dibuat dari cemper yang diisi 5 buah tangkih, membetuk tanda tambah, cemper dihulu diisi dengan tepung tawar (sebel kandel) tirtha sanjiwani tirtha kamandalu, kanannya diisi kapas (wighna halangan) Kudalini, bawah diisi segau (satru ,musuh), Pawitra samping kiri sisig (gering, merana), cendana kotoran batin (maha pawitra)

14. Di beberapa bahan termasuk byakala terdapat banten sorohan Alit. Dari beberapa buku berbeda-beda isi runtutannya; - ada yang terdiri dari peras, tulung sayut. - ada yang terdiri dari peras, soda, tulung, sayut dan pengambiyan. Mohon penjelasan napi gunanya masingmasing runtutannya itu sehingga menjadi sebuah sorohan Alit.

Jawab : Sorohan alit merupakan sarana kelengkapan banten yang memiliki karaketristik tertentu dan tujuan tertentu, misalnya jika ada kekurangan yang terdapat dalam banten tersebut maka dilengkapilah oleh banten soroan alit tersebut. Kelompok banten soroan alit Peras tulung, Peras tulung sayut, Peras ajengan pengambean, Peras tulung sayut ajengan pengambean. Silahkan dikondisikan yang terpenting ada peras

15. Apa maksud dan fungsi dari lis /bebuu tersebut?. Apa saja isi dari Lis yang kita buat untuk byakala, Duurmenggala dan prayascita. Pada banten prayascita, 
apakah kita menggunakan lis bebuu atau lis senjata? Bisakah kita tidak membuat tipat pusuh dan tipat tulud dalam pembuatan banten yang menggunakan lis bebuu?.

Jawab: Lis berasal dari kata bahasa bali (les) artinya karakteristik ciri/wujud tertentu, mebu'u artinya mebersih. Wujud yang dimaksudkan dalam persembahan adalah perwujudan yang mengandung arti sesuai dengan lontar yadnya prakerti (sahananing banten pinaka raganta twi simbul diri kita) ada simbul isi perut pada basang nguda, basang wayah, tipat pusuh, siku, ntud, (sahananing banten pinaka rupaning ida bhatara ) Lis, bu'u, padma (senjata dewa siwa) Lis senjata menggunakan busung bersifat kedewataan supaya nyambung dengan puja, om sang janur kuning pengadeganku tumurun bhatara siwa, tumurun bhatara dewata kina baktini manusa kabeh. Lis senjata penggambaran dari senjata dewata nawa sanga, (Sahananing banten pinaka ananda bhuwana) isi alam semesta. Ada simbul tumbuh-tumbuhan (paku, linting, sritetel, jan, sesapi, lawangan, tangga menek, tangga tuwung, tipat tulud. Alat kebersihan) silahkan dibuat sesuai dengan kemampuan, yang terpenting jumlahnya ganjil ada mewakili dari tangga menek tuwun, jan, lawangan (filosopi kehidupan) lawat buah, lawat nyuh, basang nguda, basang wayah, ntud, siku dll. Kalau lis alit bisa jumlahnya 27, 33 jenis, kalau lis agung besar sampai 45, 54 menurut tingkatan upacara (akan bermakna samkya 9) angka 9 angka teringgi utama dan mulia

16.Apakah dalam Pembuatan byakala kita harus menyiapkan sambuk dan tetipung? Napi makna dan esensi tetipung tersebut. Jawab : Ada beberapa referensi pada proses pelaksanaan mebyakala disertai tetimpug, sebagai simbul agni/ kekuatan/ saksi (brahma). Hal itu kita amati ketika proses mecaru tetimpugnya diarahkan diselatan (brahma sebagai penguasa arah selatan). Dan kalau mebyakala bisa cukup dengan sambuk (api takep) sebagai saksi (brahma) simbul dualitas/ rwa bhinneda, baik buruk, suka duka, lara pati, bahagia sedih, lemah peteng.

17.Sampaian Nagasari pada byakala, Durmanggala dan Prayascita apakah ada ketentuan mengenai warna dari bunganya?

Jawab:Sampian nagasari berasal dari kata naga dan sari. Naga artinya air, air artinya amertha, sedangkan sari artinya sumber, sehingga kata nagasari artinya sumber kehidupan, bulat (simbul candra bulan). Untuk warna bunga sebenarnya tidak ada ketentuannya yang terpenting bunga yang memenuhi syarat spiritual. Tetapi jika ingin bantennya indah, mengandung unsur estetika, agar muncul simbul (Byakala dominasi merah, brahma) durmenggala (dominasi gelap, hijau, hitam simbul wisnu), prayascita simbul siwa (dominasi putih, kuning ). Silahkan diatur, yang terpenting bermakna satyam, siwam, sundaram.

\section{Evaluasi Kegiatan Pelatihan Pembuatan Banten Byakala}

Di setiap sesi terakhir suatu kegiatan atau event resmi pastilah dilaksanakan penilaian sebagai bentuk evaluasi untuk dapat mengetahui sejauh mana pencapaian hasil suatu kegiatan pelatihan tersebut dan untuk mengetahui tantangan dan hambatan yang mempengaruhi ketercapaian ataupun keberhasilan suatu kegiatan. Evaluasi ialah salah satu tahap terakhir dari kegiatan karena evaluasi merupakan langkah dimana pelaksana kegiatan mengidentifikasi,dan menganalisis, serta mengukur pencapaian indikator keberhasilan suatu kegiatan sesuai dengan rencana, berdasarkan aturan dan prosedur, yang telah disepakati, hasil dari evaluasi berupa kesimpulan ataupun nilai yang ditulis pada suatu laporan (Yasa, 2021).

Mengevaluasi keberhasilan Program pelatihan tidak serta merta hanya terpaku pada indikator penilaian hasil belajar peserta pelatihan, tetapi diharapkan dapat menjangkau aspek keterampilan sebab di dalam kegiatan pelatihan pembuatan banten Upakara Byakala yang menjadi suatu tolok ukur utama berhasil atau tidaknya kegiatan ini ialah dilihat dari aspek kemampuan peserta didik untuk dapat memahami arti simbol yang terkandung didalam banten byakala sesuai dengan materi pelatihan yang telah disampaikan oleh narasumber dan indikator ketercapaian lainnya ialah sejauh mana peserta didik mampu dan trampil dalam membuat sarana banten byakaon secara mandiri dan mampu menjelaskan bahan apa saja yang menjadi unsur pembentuk banten byakala tersebut serta mengetahui kapan dan bagaimana banten byakaon itu digunakan. Dari hasil wawancara langsung terhadap peserta pelatihan pembuatan banten byakala maka kegiatan pengabdian ini telah berjalan sesuai dengan tujuan inti dilaksanakannya pelatihan ini, dan pelatihan terlaksana sesuai jadwal dan rencana pelaksanaan yang telah ditentukan, hal ini ditunjukkan dengan antusias peserta mengikuti 
kegiatan, sehingga seluruh peserta melalui proses pelatihan dengan optimal dibuktikan dengan terkumpulnya seluruh tugas yang diberikan oleh narasumber kepada peserta pelatihan baik dalam bentuk tugas materi dalam bentuk esay dan tugas praktikum yang dikumpulkan dalam bentuk video tutorial pembuatan sarana upakara banten byakala, kegiatan pelatihan terlaksana tanpa adanya perubahan jadwal (Yasa \& Wiasti, 2021).

$$
\text { Proses }
$$

pelatihan

adalah suatu aktivitas yang bernilai edukatif, yang didalamnya terdapat feedback dari peserta pelatihan atas rangsangan dalam bentuk informasi yang telah disampaikan oleh pelatih sehingga tejadi interaksi antara pendidik dan peserta didik yang menyebabkan peserta didik berusaha untuk mengadopsi dan menduplikasi inovasi maupun keterampilan yang diajarkan oleh instruktur. Namun didalam setiap kegiatan pastinya terdapat kendala ataupun hambatan, demikian halnya dengan Pelatihan Pembuatan Banten Byakala ini ada beberapa tantangan dan hambatan yaitu; 1) karena terbatasnya waktu pelasanaan kegiatan maka pelaksananan pelatihan menjadi kurang maksimal, 2) Suasana pandemi Covid-19 ini membuat peserta pelatihan merasa kurang aman dan nyaman sehingga tidak leluasa dalam beraktivitas pada kegiatan pelatihan, peserta didalam melaksanakan kegiatan pelatihan harus mematuhi Protokol kesehatan yang dimana jarak tempat duduk peserta diatur dan selama pelaksanaan kegiatan peserta menggunakan masker, 3). Latar belakang peserta yang beragam sehingga dapat mempengaruhi daya serap, pemahaman dan sudut pandang dalam menafsirkan makna filosofis yang terkandung pada simbol unsur penyusun banten byakala tersebut.

Dari beberapa kendala tersebut diatas tentunya ada terdapat keberhasilan, diantaranya 1) Sebagian besar peserta pelatihan telah memahami makna filosofis yang terkandung didalam simbol yang terdapat pada banten Byakala, serta mengetahui bagaimana cara menggunakan,dan kapan saatnya menggunakan banten byakala tersebut, 2) Peserta pelatihan sudah memiliki keterampilan dalam membuat Banten Byakala hal itu ditunjukkan dengan adanya video rekaman peserta pelatihan membuat banten byakala secara mandiri tanpa ada panduan dari narasumber ataupun mentor, 3) Peserta Pelatihan Pembuatan Banten Byakala sudah mampu menunjukan keterampilan, bakat dan rasa percaya diri yang dimilikinya dengan bersedia untuk maju menjelaskan tentang rincian susunan unsur pembentuk banten byakala, menjelaskan satu persatu makna filosofis yang terdapat pada simbol yang terkandung dalam komponen bahan penyusun banten byakala dalam Demo membuat sarana Upakara Pabersihan khususnya Banten Byakala

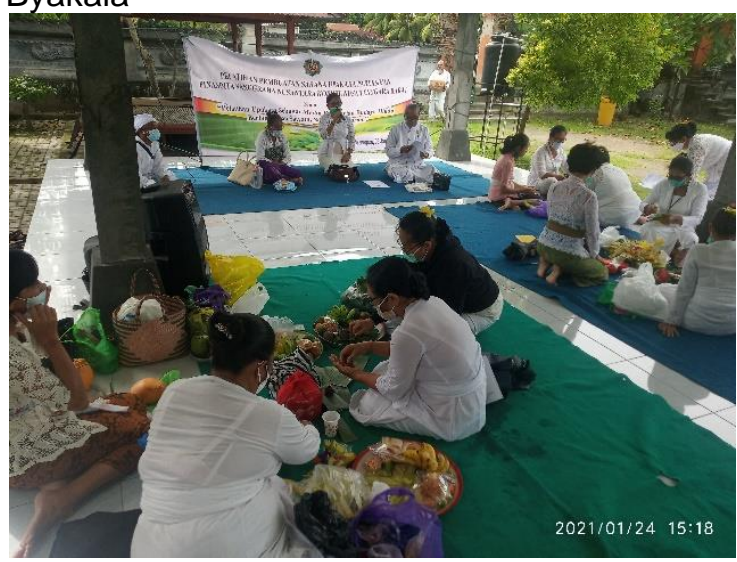

Gambar 7. Diskusi dan tanya jawab

Pembuatan Banten Byakala ( Sumber: I Made Ardika Yasa)

\section{SIMPULAN DAN SARAN}

Pelaksanaan pelatihan upakara pabersihan yang bertemakan Pelatihan Pembuatan Banten Byakala Sebagai Wahana Pelestarian Budaya Hindu Yang Berlandaskan Satyam,Siwam,Sundaram Pada Pengabdian Masyarakat diadakan di areal Pura Jagatnatha Mayura sebagai wahana pelestarian budaya Hindu sehingga dapat menciptakan karakter generasi muda Hindu yang peduli akan warisan budaya leluhur khususnya tentang tetuasan dan menyatukan persepsi terhadap makna filosofi dari simbol tetuasan yang terkandung didalam banten Byakala dengan dasar pemahaman Satyam, Siwam, Sundaram sehingga kelangsungan tradisi seni dan budaya Umat Hindu dapat tetap terjaga dan terhindar dari kepunahan.

Berdasarkan hasil evaluasi dan pembahasan tersebut dapat dikatakan bahwa kegiatan pelatihan Pembuatan Banten Byakala ini berjalan dengan lancar hal itu ditunjukkan dengan adanya peran serta aktiv masyarakat untuk mengikuti kegiatan pelatihan ini dan selama proses pelatihan peserta sangat antusias dan aktif dalam interaksi tanya jawab, dan seluruh peserta pelatihan dengan semangat dan tanpa ada rasa terbebani menyiapkan sarana dan prasarana untuk kegiatan praktek pembuatan sarana banten byakala tersebut.

Pada kegiatan pelatihan pembuatan banten Byakala ini kami mengundang narasumber/ pemateri dan pendamping yang memang ahli di bidang pembuatan sarana Upakara yaitu Pedanda Tarpini dan pendamping beberapa orang jero mangku istri 
dan sarathi banten, dengan adanya dukungan dari para pemateri dan pendamping praktikum yang professional serta berpengalaman maka kegiatan pelatihan tersebut terlaksana dengan lancar dan para peserta dengan mudah memahami materi yang disampaikan dan dengan mudah melaksanakan instruksi dari pendamping pada kegiatan praktik pembuatan sarana upakara banten byakala. Segala permasalahan/pertanyaan terkait banten byakala di lapangan/kehidupan sehari-hari diulas dan dikupas tuntas dengan sistem diskusi serta tanya jawab untuk menyatukan persepsi tentang makna dan filosofi yang terkandung didalam symbol tetuasan yang ada pada ornament banten byakala tersebut.

Walaupun kegiatan ini pesertanya terbatas hanya diikuti maksimal oleh 50 orang peserta karena kondisi Pandemi covid-19, namun hasil dari kegiatan ini tidak hanya dinikmati oleh 50 orang tersebut akan tetapi dinikmati oleh seluruh umat Hindu khususnya di Nusa Tenggara Barat dan umumnya di seluruh nusantara bahkan mancanegara sebab hasil dari kegiatan ini keluarannya dalam bentuk rekaman video kegiatan yang di unggah pada akun media sosial seperti youtube, facebook, dan dalam bentuk buku pedoman serta jurnal, dengan adanya kegiatan pelatihan ini maka alumni dari peserta pelatihan diharapkan dapat melanjutkan dan menyebarkan pengetahuan dan keterampilan dibidang metetuasan ini kepada sanak saudara, teman dan umat Hindu lainnya serta diharapkan dapat membentuk Unit Kegiatan Srati Banten.

Seperti halnya kegiatan pelatihan pada umumnya, begitu halnya kegiatan pelatihan ini juga mengadakan evaluasi dan monitoring walaupun via daring, kegiatan evaluasi yaitu dengan cara memberikan kuisioner, presentasi via zoom meeting dan pengiriman video praktikum mandiri, monitoring dengan cara memantau perkembangan alumni peserta pelatihan banten byakala hingga terbentuknya unit kegiatan sarathi banten yang dapat menunjang terlaksananya kegiatan pelatihan Upakara pada sesi berikutnya sehingga kegiatan pelatihan ini dapat terlaksana secara maksimal dan berkesinambungan.

\section{UCAPAN TERIMAKASIH}

Tiada suatu kesuksesan yang diperoleh secara instan begitu juga dengan pelaksanaan kegiatan pelatihan Pembuatan Banten Byakala ini, tidak akan berjalan lancar dan sukses tanpa adanya dukungan dari berbagai pihak, ucapan terimakasih yang sedalam-dalamnya kami sampaikan kepada Parisada Hindu Dharma Indonesia Provinsi Nusa Tenggara Barat, berkat dukungannya secara moril sehingga pelatihan ini dapat berjalan dengan lancar, ucapan terimakasih juga kami sampaikan kepada Bidang Bimbingan Masyarakat Hindu Kantor Kementerian Agama Provinsi Nusa Tenggara Barat yang selalu mensuport dan memotivasi sehingga kegiatan pelatihan pembuatan banten byakala ini dapat terselenggara sesuai rencana dan tidak lupa juga kami haturkan salam terimakasih kepada Pinandita Sanggraha Nusantara Kabupaten/Kota se-Nusa Tenggara Barat dan Umat Hindu atas dukungannya dalam pelatihan pembuatan banten Byakala ini.

\section{DAFTAR RUJUKAN}

Ahmad, M. Y., \& Tambak, S. (2017). Hubungan Metode Tanya Jawab dengan Minat Belajar Peserta Didik pada Mata Pelajaran Pendidikan Agama Islam. Jurnal Pendidikan Agama Islam Al-Thariqah, 2(1), $89-110$. https://doi.org/10.25299/althariqah.2017.v ol2(1).650

Arwati, M. S. (2003). Byakala, Tebasan Durmenggala.

Gunada, I. W. A. (2020). Ajaran Agama Hindu Sebagai Inspirasi Penciptaan Karya Seni Lukis Tradisional Bali. Gorga : Jurnal Seni Rupa, 9(1), 158-165. https://doi.org/10.24114/gr.v9i1.18492

Gunada, I. W. A. (2020). Nilai Susila dalam Sloka Hindu untuk Penguatan Pendidikan karakter Bagi Peserta Didik. Media Bina Ilmiah, 14(8), 3035-3054. https://doi.org/10.33758/mbi.v14i8.483

Gunada, I. W. A. (2021). Konsepsi Agama dan Seni Rupa dalam Rurub Kajang Tutuan (Kajian Estetika Hindu). Mudra Jurnal Seni Budaya, 36(2), 153-162. https://doi.org/10.31091/mudra.v36i2.107 2

Latifah, L. (2013). Metode Diskusi Kelompok Berbasis Inquiri Untuk Meningkatkan Hasil Belajar Fisika Di SMA. 02.

Sudana, A. I. B. (2001). Indik Bebantenan Lombok. Departemen Agama Kab. Lombok Barat.

Surayin, I. A. P. (2002). Melangkah Ke Arah Persiapan Upakara Upacara Yadnya. Paramita Surabaya.

Yasa, I. M. A. (2021). Optimalisasi Pengabdian Masyarakat Pada Sekolah PAUD Binaan. Selaparang: Jurnal Pengabdian Masyarakat Berkemajuan, 4(2), 179-187. https://doi.org/10.31764/jpmb.v4i2.4387

Yasa, I. M. A., \& Wiasti, N. K. (2021). Pelatihan Pembuatan Sarana Upakara Pabersihan Dalam Pengabdian Masyarakat Pinandita Sanggraha Nusantara Koordinator Wilayah Nusa Tenggara Barat. 
Selaparang: Jurnal Pengabdian Masyarakat Berkemajuan, 4(2), 291-301. https://doi.org/10.31764/jpmb.v4i2.4442 